\title{
Genetic diversity and population structure analysis of Kala bhat (Glycine max (L.) Merrill) genotypes using SSR markers
}

\author{
Yegappa Hipparagi ${ }^{1}$, Rakesh Singh ${ }^{2 *}$, Debjani Roy Choudhury ${ }^{2}$ and Veena Gupta ${ }^{3}$
}

\begin{abstract}
Background: Kala bhat (Black soybean) is an important legume crop in Uttarakhand state, India, due to its nutritional and medicinal properties. In the current study, the genetic variabilities present in Kala bhat were estimated using SSR markers and its variability was compared with other improved soybean varieties cultivated in Uttarakhand state, India.

Results: Seventy-five genotypes cultivated in different districts of Uttarakhand were collected, and molecular analysis was done using 21 SSR markers. A total of 60 alleles were amplified with an average of 2.85 alleles per locus. The mean value of gene diversity and PIC was estimated to be 0.43 and 0.36 , respectively. The unrooted phylogenetic tree grouped soybean genotypes into three major clusters, where, yellow seed coat (improved varieties) genotypes were grouped in one cluster, while reddish brown (improved varieties) and Kala bhat showed intermixing. Population structure divided the soybean genotypes into six different populations. AMOVA analysis showed $12 \%$ variance among the population, $66 \%$ variance among individual and $22 \%$ variance was observed within individuals. Principal Coordinate Analysis (PCOA) also showed that yellow seed coat genotypes were grouped in one cluster, whereas, the Kala bhat showed scattered distribution and few genotypes of Kala bhat showed grouping with red and yellow genotypes.

Conclusions: The different genetic diversity parameters used in the present study indicate that Kala bhat genotypes were more diverse than the yellow seed coat and brown seed coat colour genotypes. Therefore, Kala bhat genotypes can be a good source for the soybean breeding programme due to its better genetic diversity as well as its medicinal properties.
\end{abstract}

Keywords: Soybean, Genetic diversity, SSR markers, Seed colour

\section{Background}

Soybean (Glycine max (L.) Merr) is an important legume crop which contains $37-42 \%$ protein, $17-24 \%$ oil and $35 \%$ carbohydrates [1], that served as an excellent source of oil and protein for human consumption and animal feed. The wild and cultivated soybeans showed significant phenotypic diversity but the small reproductive difference, and they have very similar genomes in both its size and content [2]. Soybean is grown under varied climatic conditions and geographical locations in India. It occupies an area of 10.8 million hectare and accounting

\footnotetext{
* Correspondence: singhnbpgr@yahoo.com

${ }^{2}$ Division of Genomic Resources, ICAR-National Bureau of Plant Genetic

Resources, New Delhi 110 012, India

Full list of author information is available at the end of the article
}

to a production of 11.5 million tone with the productivity of $1065 \mathrm{~kg} / \mathrm{ha}$ [3]. A potential source of protein and oil makes soybeans a large share in human nutrition, and also improves soil fertility therefore; soybean is also an important crop for research [4].

In soybean, evaluation of genetic diversity is enhanced by the use of DNA markers. Researchers have studied the genetic divergence among soybean genotypes for various agronomic traits [5-8] with molecular markers [9-11]. Among different DNA markers, restriction fragment length polymorphisms (RFLPs), random amplified polymorphic DNAs (RAPDs), amplified fragment length polymorphisms (AFLPs), single nucleotide polymorphisms (SNPs) and microsatellites or simple sequence repeats 
(SSRs) have been extensively used in soybean, each with its own advantages and limitations [12-17].

Black seed coat soybean, locally known by different names such as Bhat, Bhatmash and Kala bhat is grown in Kumaon and Garhwal region and in frontiers of Uttarakhand state [18]. In Uttarakhand, these soybean varieties are commonly known as Kala Bhat. It is believed that soybean was introduced by traders via Myanmar from Indonesia. As a result, it has been traditionally grown on a small scale in states like Himachal Pradesh, Kumaon and Garhwal hills of Uttarakhand, East Bengal, Khasi hills and small parts of central India. Kala bhat is also considered as the treasure trove of different medicinal properties. Kala bhat and its products are the richest sources of iso-flavones. Kala bhat, in Uttarakhand is grown in 5734 ha area, with a production and productivity is 5636 tonne and $9.82 \mathrm{q} / \mathrm{ha}$, respectively (Anonymous, 2011). A traditional cultivar of Kala bhat is much low yielder than normal soybean varieties hence this can be improved further by crossing with diverse exotic as well as indigenous germplasm. Morphological characterization of 21 soybean cultivars was done by Oda et al. [19] and 24 Kala bhat genotypes was done by Bhartiya et al. [20].

Analyses of the genetic variation and population structure of Kala bhat genotypes are important for their effective conservation and utilization of the valuable genetic resource. The present study was done to estimate the genetic variability and population structure present in Kala bhat cultivated in Uttarakhand state using SSR markers, as the information on the level of diversity present in local landraces (Kala bhat) and population structure had not been studied systematically. The genetic diversity of Kala bhat was also compared with other improved soybean varieties cultivated in Uttarakhand.

\section{Methods}

\section{Collection of plant materials}

Seeds of 75 soybean genotypes were procured from NBPGR regional station located at Bhowali, Uttarakhand, India. The Seeds were sown in pots under controlled conditions inside the Green house of NBPGR, New Delhi. Black seed coat genotypes were the landraces (Kala bhat) whereas, reddish-brown and yellowishwhite genotypes were improved varieties, which were introduced earlier and naturalized as the population in that agro-ecological region. The leaf samples were collected at 3-4 leaves stage for DNA isolation. The details of each genotype along with passport data, National ID, i.e. Indigenous Collection (IC) number, cultivar name, seed colour, district, region and state are given in Table 1 .

\section{DNA extraction}

Five grams of young fresh leaves were crushed in liquid nitrogen using a motor pestle and DNA was isolated using CTAB method [21]. The DNA quality was first checked on $0.8 \%$ agarose gel and then quantified using Nanodrop (Thermo Fisher, USA). A working concentration of $10 \mathrm{ng} / \mu \mathrm{l}$ DNA stock was prepared for all the 75 soybean genotypes and stored at $4{ }^{\circ} \mathrm{C}$.

\section{Genotyping of soybean genotypes using SSR markers}

Total 51 SSR markers were selected for initial screening. Gradient PCR was done for each primer with selected soybean samples to standardize the temperature for amplification (Ta). 21 SSR primers (Table 2) out of 51 showed good amplification and were considered for further study. These 21 primers were subjected to PCR analysis with 75 soybean samples.

PCR reaction was set in a total volume of $10 \mu \mathrm{l}$ containing $2 \mu \mathrm{l}$ genomic DNA (10 ng/ $\mu \mathrm{l}), 1 \mu \mathrm{l}$ of $10 \mathrm{X}$ buffer, $0.8 \mu \mathrm{l}$ of $25 \mathrm{mM} \mathrm{MgCl}, 0.2 \mu \mathrm{l}$ of $10 \mathrm{mM}$ dNTPs, $0.2 \mu \mathrm{l}$ of each primer ( $10 \mathrm{nmol}), 0.2 \mu \mathrm{l}$ of Taq DNA polymerase (Fermentas, Life Sciences, USA) and $5.6 \mu$ l distilled water. Amplification was performed in a thermocycler (G Storm, UK) using following program; Initial denaturation at $94{ }^{\circ} \mathrm{C}$ for $4 \mathrm{~min}$ followed by 36 cycles of $94{ }^{\circ} \mathrm{C}$ for $30 \mathrm{~s}$, Ta for $45 \mathrm{~s}, 72{ }^{\circ} \mathrm{C}$ for $1 \mathrm{~min}$ and a final extension at $72{ }^{\circ} \mathrm{C}$ for $10 \mathrm{~min}$. The amplified products were analyzed on $4 \%$ metaphor agarose gel for $4 \mathrm{~h}$ at a constant supply of $120 \mathrm{~V}$. Gel pictures were recorded using gel documentation System (Alpha Imager ${ }^{\circ}$ USA).

\section{Statistical analysis}

SSR bands generated near expected product size were scored visually for all 75 genotypes of Soybean. The band size of amplified products was determined by comparing with 100 bp DNA ladder (Fermentas, Life Sciences, USA). The SSR bands scored in soybean genotypes was subjected to statistical analysis. Major allele frequency, gene diversity, heterozygosity and polymorphic information content (PIC) for each locus for SSR markers were calculated using Power Marker 3.25 [22]. In addition, genetic distances across the soybean genotypes were calculated using Power Marker 3.25 , and a phylogenetic tree was constructed and viewed in Mega version 6 [23] . Principle Coordinate Analysis (PCoA) and Analysis of Molecular Variance (AMOVA) were performed using software GenAlEx V6.5 [24]. The model-based program, STRUCTURE 2.3.3 [25] was used to infer the population structure. For each $\mathrm{K}$, three replications were run. Each run was implemented over a burn-in period of 100,000 steps with 100,000 Monte Carlo Markov Chain replicates. The membership of each genotype was run for a range of genetic clusters from the value of $K=1$ to 20 by 
Table 1 List of Soybean genotypes used in the study with their cultivar name, IC numbers, seed coat colour, district, region and state

\begin{tabular}{|c|c|c|c|c|c|c|}
\hline S. No. & Cultivar name & IC numbers & Seed coat colour & District & Region & State \\
\hline 1 & Bhatt & IC281596 & Imperfect black & Bageshwar & Kumaon & Uttarakhand \\
\hline 2 & Soybean & IC281602 & Yellowish white & Bageshwar & Kumaon & Uttarakhand \\
\hline 3 & Bhatt & IC281616 & Imperfect black & Chamoli & Garhwal & Uttarakhand \\
\hline 4 & Soybean & IC281618 & Yellowish white & Almora & Kumaon & Uttarakhand \\
\hline 5 & Soybean & IC281629 & Yellowish white & Almora & Kumaon & Uttarakhand \\
\hline 6 & Soybean & IC281644 & Yellowish white & Almora & Kumaon & Uttarakhand \\
\hline 7 & Soybean & IC281652 & Yellowish white & Almora & Kumaon & Uttarakhand \\
\hline 8 & Soybean & IC281655 & Yellowish white & Almora & Kumaon & Uttarakhand \\
\hline 9 & Soybean & IC281671 & Yellowish white & Almora & Kumaon & Uttarakhand \\
\hline 10 & Soybean & IC281684 & Yellowish white & Almora & Kumaon & Uttarakhand \\
\hline 11 & Soybean & IC281694 & Yellowish white & Tehri & Garhwal & Uttarakhand \\
\hline 12 & Kala bhatt & IC281815 & Imperfect black & Almora & Kumaon & Uttarakhand \\
\hline 13 & Bhatt & IC281838 & Imperfect black & Almora & Kumaon & Uttarakhand \\
\hline 14 & Soybean & IC281843 & Yellowish white & Almora & Kumaon & Uttarakhand \\
\hline 15 & Soybean & IC316141 & Yellowish white & Bhowali & Kumaon & Uttarakhand \\
\hline 16 & Bhatt & IC316142 & Imperfect black & Bhowali & Kumaon & Uttarakhand \\
\hline 17 & Soybean & IC316154 & Yellowish white & Bhowali & Kumaon & Uttarakhand \\
\hline 18 & Bhatt & IC316155 & Imperfect black & Nainital & Kumaon & Uttarakhand \\
\hline 19 & Bhatt & IC316163 & Imperfect black & Nainital & Kumaon & Uttarakhand \\
\hline 20 & Kala soybean & IC316170 & Imperfect black & Almora & Kumaon & Uttarakhand \\
\hline 21 & Bhatt & IC316171 & Imperfect black & Almora & Kumaon & Uttarakhand \\
\hline 22 & Kala soybean & IC316172 & Imperfect black & Almora & Kumaon & Uttarakhand \\
\hline 23 & Bhatt & IC316178 & Imperfect black & Almora & Kumaon & Uttarakhand \\
\hline 24 & Soybean & IC316181 & Yellowish white & Bhowali & Kumaon & Uttarakhand \\
\hline 25 & Soybean & IC316182 & Yellowish white & Nainital & Kumaon & Uttarakhand \\
\hline 26 & Bhatt & IC316183 & Imperfect black & Nainital & Kumaon & Uttarakhand \\
\hline 27 & Bhatt & IC316184 & Imperfect black & Nainital & Kumaon & Uttarakhand \\
\hline 28 & Bhatt & IC316186 & Imperfect black & Nainital & Kumaon & Uttarakhand \\
\hline 29 & Soybean & IC316188 & Yellowish white & Nainital & Kumaon & Uttarakhand \\
\hline 30 & Kala bhatt & IC316192 & Imperfect black & Nainital & Kumaon & Uttarakhand \\
\hline 31 & Kala soybean & IC316193 & Imperfect black & Almora & Kumaon & Uttarakhand \\
\hline 32 & Bhatt & IC317428 & Imperfect black & Chamoli & Garhwal & Uttarakhand \\
\hline 33 & Bhatt & IC317431 & Yellowish white & Chamoli & Garhwal & Uttarakhand \\
\hline 34 & Bhatt & IC317437 & Imperfect black & Chamoli & Garhwal & Uttarakhand \\
\hline 35 & Bhatt & IC317465 & Reddish brown & Chamoli & Garhwal & Uttarakhand \\
\hline 36 & Soybean & IC317578 & Yellowish white & Dehradun & Garhwal & Uttarakhand \\
\hline 37 & Soybean & IC317581 & Yellowish white & Dehradun & Garhwal & Uttarakhand \\
\hline 38 & Bhatt & IC317660 & Imperfect black & Dehradun & Garhwal & Uttarakhand \\
\hline 39 & Bhatt & IC317663 & Imperfect black & Dehradun & Garhwal & Uttarakhand \\
\hline 40 & Soybean & IC337280 & Yellowish white & Pauri & Garhwal & Uttarakhand \\
\hline 41 & Bhatt & IC338509 & Imperfect black & Almora & Kumaon & Uttarakhand \\
\hline 42 & Bhatt & IC338622 & Imperfect black & Pauri & Garhwal & Uttarakhand \\
\hline 43 & Bhatt & IC338626 & Imperfect black & Nainital & Kumaon & Uttarakhand \\
\hline 44 & Soybean & IC338702 & Imperfect black & Champawat & Kumaon & Uttarakhand \\
\hline
\end{tabular}


Table 1 List of Soybean genotypes used in the study with their cultivar name, IC numbers, seed coat colour, district, region and state (Continued)

\begin{tabular}{|c|c|c|c|c|c|c|}
\hline 45 & Soybean & IC338713 & Imperfect black & Champawat & Kumaon & Uttarakhand \\
\hline 46 & Soybean & IC338717 & Imperfect black & Champawat & Kumaon & Uttarakhand \\
\hline 47 & Soybean & IC338720 & Yellowish white & Champawat & Kumaon & Uttarakhand \\
\hline 48 & Soybean & IC338729 & Imperfect black & Champawat & Kumaon & Uttarakhand \\
\hline 49 & Soybean & IC338732 & Reddish brown & Champawat & Kumaon & Uttarakhand \\
\hline 50 & Soybean & IC338749 & Imperfect black & Champawat & Kumaon & Uttarakhand \\
\hline 51 & Soybean & IC419875 & Yellowish white & Chamoli & Garhwal & Uttarakhand \\
\hline 52 & Bhatt & IC419896 & Imperfect black & Chamoli & Garhwal & Uttarakhand \\
\hline 53 & Bhatt & IC419909 & Imperfect black & Chamoli & Garhwal & Uttarakhand \\
\hline 54 & Kala bhatt & IC430009 & Imperfect black & Bageshwar & Kumaon & Uttarakhand \\
\hline 55 & Soybean & IC430038 & Yellowish white & Bageshwar & Kumaon & Uttarakhand \\
\hline 56 & Soybean & IC430041 & Yellowish white & Bageshwar & Kumaon & Uttarakhand \\
\hline 57 & Soybean & IC430063 & Yellowish white & Bageshwar & Kumaon & Uttarakhand \\
\hline 58 & Kala bhatt & IC430066 & Imperfect black & Bageshwar & Kumaon & Uttarakhand \\
\hline 59 & Soybean & IC430075 & Imperfect black & Bageshwar & Kumaon & Uttarakhand \\
\hline 60 & Soybean & IC430076 & Yellowish white & Bageshwar & Kumaon & Uttarakhand \\
\hline 61 & Black bhatt & IC436967 & Imperfect black & Rudraprayag & Garhwal & Uttarakhand \\
\hline 62 & Bhatt & IC444239 & Imperfect black & Pithoragarh & Kumaon & Uttarakhand \\
\hline 63 & Bhatt & IC444241 & Imperfect black & Pithoragarh & Kumaon & Uttarakhand \\
\hline 64 & Bhatt & IC444249 & Reddish brown & Pithoragarh & Kumaon & Uttarakhand \\
\hline 65 & Kala bhatt & IC469759 & Imperfect black & Champawat & Kumaon & Uttarakhand \\
\hline 66 & Kala bhatt & IC469767 & Imperfect black & Champawat & Kumaon & Uttarakhand \\
\hline 67 & Kala bhatt & IC469833 & Imperfect black & Champawat & Kumaon & Uttarakhand \\
\hline 68 & Soybean & IC469881 & Yellowish white & Pithoragarh & Kumaon & Uttarakhand \\
\hline 69 & Kala bhatt & IC469902 & Imperfect black & Pithoragarh & Kumaon & Uttarakhand \\
\hline 70 & Kala bhatt & IC524256 & Imperfect black & Pauri & Garhwal & Uttarakhand \\
\hline 71 & Bhatt & IC538013 & Imperfect black & Nainital & Kumaon & Uttarakhand \\
\hline 72 & Bhatt & IC538042 & Imperfect black & Nainital & Kumaon & Uttarakhand \\
\hline 73 & Bhatt & IC538070 & Yellowish white & Champawat & Kumaon & Uttarakhand \\
\hline 74 & Kala bhatt & IC548612 & Imperfect black & Almora & Kumaon & Uttarakhand \\
\hline 75 & Kala bhatt & IC548623 & Imperfect black & Chamoli & Garhwal & Uttarakhand \\
\hline
\end{tabular}

taking admixture model and correlated allele frequency into account. LnPD derived for each $\mathrm{K}$ was then plotted to find the plateau of the $\Delta \mathrm{K}$ values [26]. The "Structure harvester" program was used (http: //taylor0. biology.ucla.edu) to determine the final population. Venn diagram analysis was performed to identify common accessions between cluster and population using software Venny 2.1 [27].

\section{Results}

Total 21 SSR primers were used for genetic diversity study of 75 soybean genotypes. A total of 60 alleles were amplified with an average of 2.85 alleles per locus. The number of alleles amplified per SSR primer varied from 2 to 4 (Table 2) and maximum numbers of alleles were amplified with primer Sat180, Sat600, Sat554 and Sat478 (four alleles). Gene diversity varied from 0.72 (Satt 180) to 0.11 (Satt 389 and Satt 285) with a mean value of 0.43 . The heterozygosity ranged from 0.00 (Satt385, Satt415, Satt277, Satt183, Satt247, Satt584) to 0.98 (Satt 306). Major allele frequency was lowest for Satt180 (0.35) and maximum for Satt389 and Satt285 (0.94). The maximum PIC was observed for primer Satt $180(0.66)$ and the minimum was observed for Satt285 and Satt389 (0.10) with a mean value of 0.36 . (Table 2 ). 
Table 2 List of SSR primers used for genotyping of 75 soyabean genotypes along with their product size, no. of alleles amplified, gene diversity, heterozygosity and PIC value

\begin{tabular}{|c|c|c|c|c|c|c|c|c|}
\hline Marker & $\begin{array}{l}\text { Size } \\
\text { (bp) }\end{array}$ & Forward primer & Reverse primer & $\begin{array}{l}\text { Major allele } \\
\text { frequency }\end{array}$ & $\begin{array}{l}\text { Allele } \\
\text { No }\end{array}$ & $\begin{array}{l}\text { Gene } \\
\text { diversity }\end{array}$ & Heterozygosity & PIC \\
\hline sat005 & 141 & TATCCTAGAGAAGAACTAAAAAA & GTCGATTAGGCTTGAAATA & 0.6000 & 2.0000 & 0.4800 & 0.0571 & 0.3648 \\
\hline sat385 & 310 & AATCGAGGATTCACTTGAT & CATTGGGCCACACAACAAC & 0.6081 & 2.0000 & 0.4766 & 0.0000 & 0.3630 \\
\hline sat415 & 297 & GCGTCTCCCTTAATCTTCAAGC & GCGTGTGACGGTTCAAAATGATAGTT & 0.6197 & 3.0000 & 0.4999 & 0.0000 & 0.4104 \\
\hline sat577 & 119 & CAAGCTTAAGTCTTGGTCTTCTCT & GGCCTGACCCAAAACTAAGGGAAGTG & 0.6884 & 3.0000 & 0.4637 & 0.0145 & 0.4039 \\
\hline sat180 & 242 & TCGCGTTTGTCAGC & TTGATTGAAACCCAACTA & 0.3542 & 4.0000 & 0.7210 & 0.1250 & 0.6689 \\
\hline sat277 & 243 & GGTGGTGGCGGGTTACTATTACT & CCACGCTTCAGTTGATTCTTACA & 0.6923 & 2.0000 & 0.4260 & 0.0000 & 0.3353 \\
\hline sat422 & 250 & ATTAGGGGAGGGGAGGTAAAAAGT & TGAAGGCCCGATATCCAAATAAA & 0.5208 & 3.0000 & 0.5651 & 0.0139 & 0.4742 \\
\hline sat600 & 195 & GCGCAGGAAAAAAAAACGCTITTATT & GCGCAATCCACTAGGTGTTAAT & 0.5625 & 4.0000 & 0.6189 & 0.1389 & 0.5753 \\
\hline sat389 & 232 & GCGGCTGGTGTATGGTGAAATCA & GCGCCAAAACCAAAAGTTATATC & 0.9400 & 2.0000 & 0.1128 & 0.0400 & 0.1064 \\
\hline sat411 & 97 & TGGCCATGTCAAACCATAACAACA & GCGTTGAAGCCGCCTACAAATATAAT & 0.5462 & 2.0000 & 0.4957 & 0.0154 & 0.3729 \\
\hline sat554 & 261 & GCGATATGCTTTGTAAGAAAATTA & GCGCAAGCCCAAATATTACAAATT & 0.5530 & 4.0000 & 0.5874 & 0.0758 & 0.5200 \\
\hline sat285 & 236 & GCGACATATTGCATTAAAAACATACTT & GCGGACTAATTCTATTTTACACCAACAAC & 0.9400 & 2.0000 & 0.1128 & 0.0133 & 0.1064 \\
\hline sat183 & 240 & TAGGTCCCAGAATTTCATTG & CACCAACCAGCACAAAA & 0.6800 & 2.0000 & 0.4352 & 0.0000 & 0.3405 \\
\hline sat431 & 250 & GCGTGGCACCCTTGATAAATAA & GCGCACGAAAGTIITCTGTAACA & 0.4857 & 3.0000 & 0.6171 & 0.0571 & 0.5409 \\
\hline sat247 & 221 & GCGCCCATGTGGCTATTTCTITATTT & GCGGATCAATAATAAACAAAGTGACAA & 0.8933 & 2.0000 & 0.1906 & 0.0000 & 0.1724 \\
\hline sat175 & 163 & GACCTCGCTCTCTGTTTCTCAT & GGTGACCACCCCTATTCCTTAT & 0.8733 & 2.0000 & 0.2212 & 0.0133 & 0.1968 \\
\hline sat306 & 212 & GCGCTTAAGGACACGGATGTAAC & GCGTCTCTTTCGATTGTTCTATTAG & 0.5074 & 2.0000 & 0.4999 & 0.9853 & 0.3749 \\
\hline sat255 & 141 & GCGCTITTAGCGTCGTCTGGC & ТАССССТСТСТТАТТСТTСТT & 0.8493 & 3.0000 & 0.2597 & 0.0274 & 0.2324 \\
\hline sat584 & 189 & GCGCCCAAACCTATTAAGGTATGAACA & GCGGGTCAGAAGATGCTACCAAACTCT & 0.7719 & 2.0000 & 0.3521 & 0.0000 & 0.2901 \\
\hline sat420 & 232 & GCGTATTCAGCAAAAAAATATCAA & TTATCGCACGTGTAAGGAGACAAAT & 0.7800 & 2.0000 & 0.3432 & 0.0133 & 0.2843 \\
\hline \multirow[t]{2}{*}{ sat478 } & 190 & CAGCCAAGCAAAAGATAAATAATA & TCCCCCACAAGAGAACAAGAAGGT & 0.5423 & 4.0000 & 0.6341 & 0.8592 & 0.5886 \\
\hline & & & Mean & 0.6671 & 2.6190 & 0.4340 & 0.1166 & 0.3677 \\
\hline
\end{tabular}

\section{Hierarchical cluster analysis}

Soybean genotypes were grouped into three major clusters (Fig. 1). Kala bhat got distributed in all the three clusters whereas, brown seed coat colour soybean got grouped only into cluster3 that was mainly dominated by Kala bhat, which shows that there is mixing up of the genetic background between them. However yellow seeded soybeans were grouped into only cluster1 but five genotypes (IC316142, IC430009, IC316172, IC316192 and IC317660) of Kala bhat also grouped with yellow seed coat colour genotypes in cluster1. This hierarchical cluster analysis showed that Kala bhat is sharing genetic similarity with both, yellow and brown seed coat colour soybean, but, there is no sharing of genetic similarity between brown and yellow seed coat colour soybeans.

\section{Population structure}

The 75 soybean genotypes got distributed into six populations (Figs. 2 and 3). Seven pure and five admix individuals were present in population1; twelve pure and eight admix individuals were in population 2; five pure and seven admix individuals in population 3; eight pure and four admix individuals in population 4, 10 pure and three admix individuals in population 5 , and three pure and three admix individuals in population 6. Mean Fst value for pop1, pop2, pop3, pop4, pop5 and pop6 were $0.464,0.498,0.332,0.608,0.345$, and 0.688 respectively with a mean alpha value of 0.058 . The allele frequency divergence among populations is given in Table 3. Average distances (expected heterozygosity) between individuals in the same cluster were between the range of 0.148 for cluster 6 and 0.378 for cluster 5. Population 1, 2 and 3 were dominated by Kala bhat and brown seed coat colour genotypes (highlighted with brown box) got distributed in all the three populations (Fig. 2) while, population 4, 5 and 6 were dominated by yellow seed coat colour genotypes (Fig. 2). Population structure based grouping supports the hierarchical cluster analysis and genotypes grouped in cluster1 corresponds to pop4,5 and 6 while genotypes grouped in cluster3 corresponds to pop1, 2 and 3.

\section{Analysis of molecular variance (AMOVA)}

Analysis of molecular variance (AMOVA) of soybean genotypes based on seed coat color was performed to analyze the distribution of genetic diversity between and 


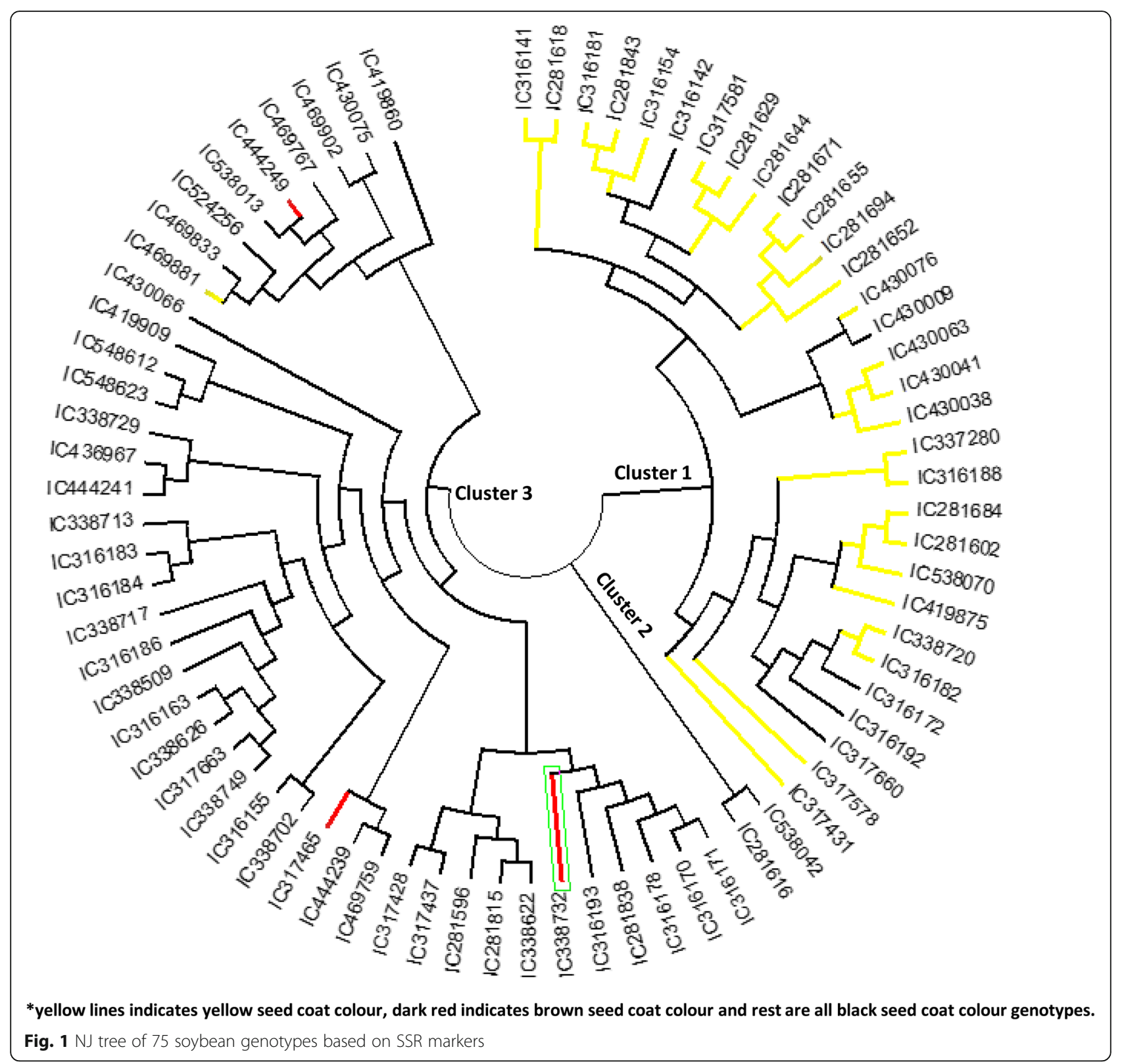

within the populations. AMOVA analysis showed 12\% diversity among populations, $22 \%$ diversity within individuals and a maximum of $66 \%$ diversity among individuals (Table 4).

\section{Principal coordinate analyses (PCoA)}

Principal coordinate analyses (PCoA) showed two distinct groups represented by Kala bhat and yellow seed coat colour soybean respectively. The brown seed coat colour soybean got distributed in both the groups. The yellow seed coat colour soybean was confined to one group, a similar pattern was also observed during the cluster analysis. The first three axes of PCoA have explained a cumulative percent variation of $33.15 \%$ (Fig. 4).
This shows large diversity exists in the genotypes studied.

\section{Co-linearity between hierarchical cluster and model based population analysis}

Since the similar pattern of a grouping of genotypes was observed in the hierarchical cluster as well as in population structure, therefore, the Co-linearity between a grouping of genotypes in hierarchical cluster and model based population structure was confirmed using Venn diagram (Fig. $5 \mathrm{a}$ and b). The Venn diagram (Fig. 5a) showed that, out of 32 genotypes tested; 30 genotypes were common between population 4, 5, 6 and cluster 1 (93.8\%) similarly, Venn diagram (Fig. 5b) 


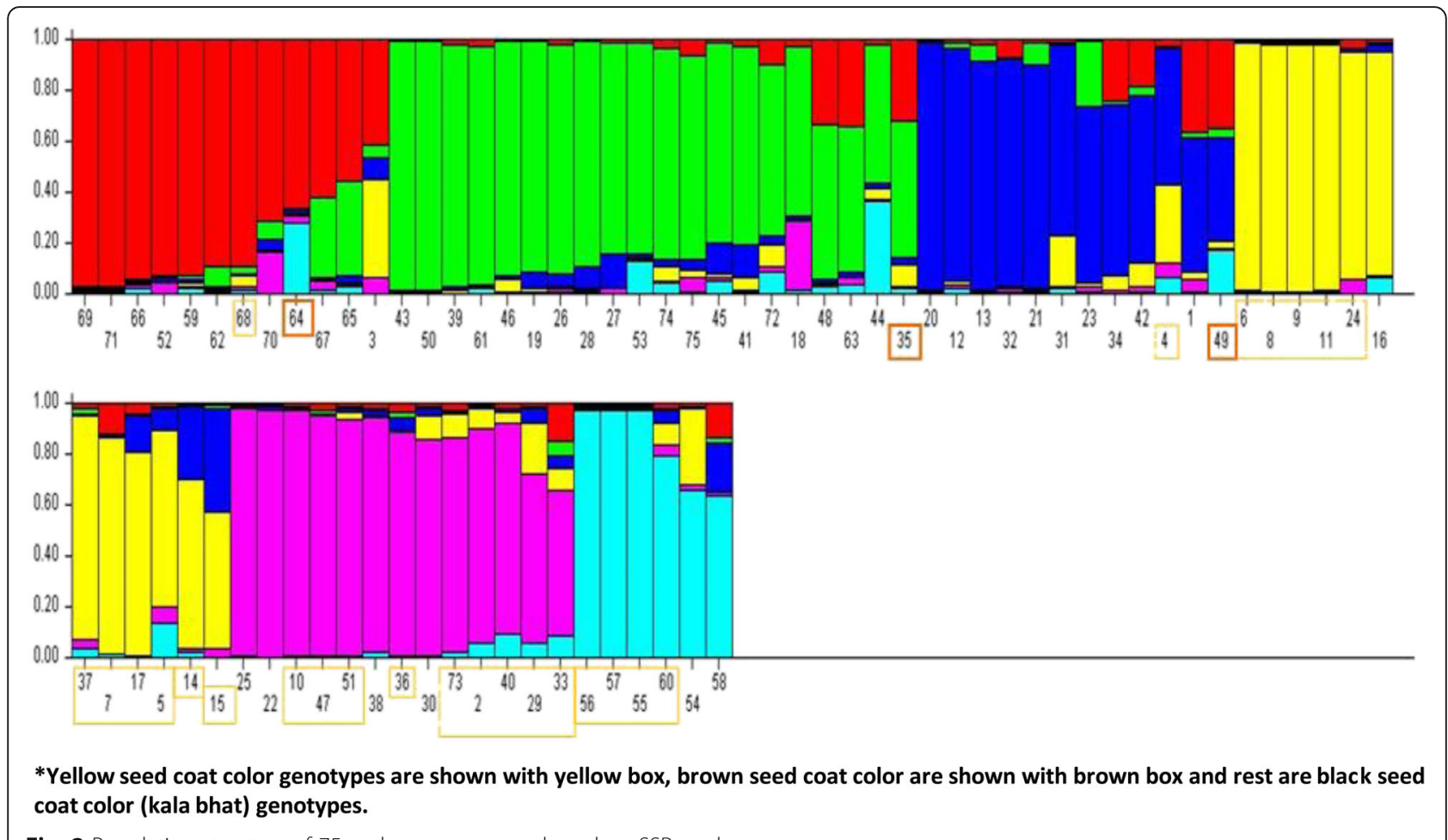

Fig. 2 Population structure of 75 soybean genotypes based on SSR markers

showed that 41 genotypes were common between population 1, 2, 3 and cluster 3 (91.1\%). This study supports that grouping of soybean genotypes based on the hierarchical cluster and model based approaches were more than $90 \%$ similar.

\section{Discussion}

The assessment of genetic diversity is not only important for crop improvement but also important for the efficient management and protection of the available genetic resource. The reliable and authentic results of

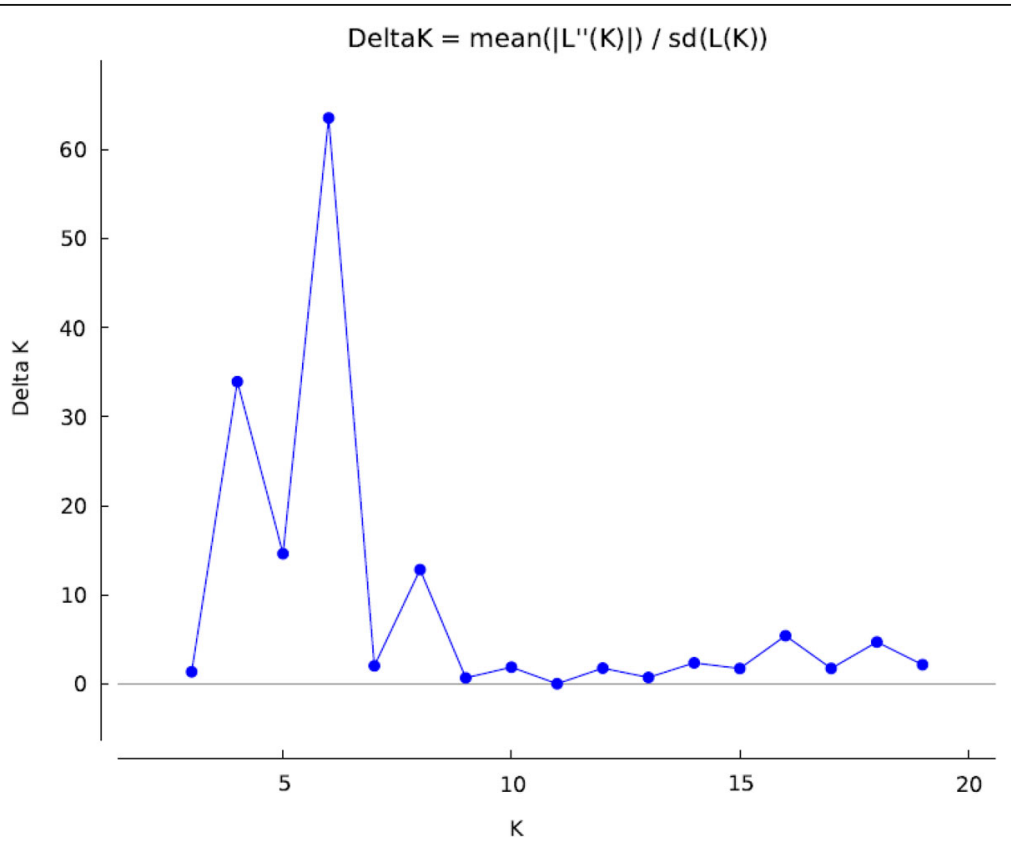

Fig. 3 Estimation of population using $L n P(D)$ derived $\Delta k$ for $k$ from 1 to20 
Table 3 Allele-frequency divergence among populations computed using estimates of $\mathrm{P}$ (Model based approach)

\begin{tabular}{lllllll}
\hline & POP1 & POP2 & POP3 & POP4 & POP5 & POP6 \\
\hline POP1 & - & 0.1944 & 0.1781 & 0.2448 & 0.1634 & 0.1877 \\
POP2 & 0.1944 & - & 0.1609 & 0.2932 & 0.3036 & 0.2782 \\
POP3 & 0.1781 & 0.1609 & - & 0.1892 & 0.2029 & 0.2013 \\
POP4 & 0.2448 & 0.2932 & 0.1892 & - & 0.2197 & 0.1772 \\
POP5 & 0.1634 & 0.3036 & 0.2029 & 0.2197 & - & 0.2044 \\
POP6 & 0.1877 & 0.2782 & 0.2013 & 0.1772 & 0.2044 & - \\
\hline
\end{tabular}

molecular profiling have made it preferred in genetic diversity study. The molecular study is less influenced by environmental fluctuations, stands another reason for its preference in breeding [28]. Also, it is less biased when compared with estimates obtained by the coefficient of parentage and phenotypic characters [19]. Genetic diversity study has several aspects, first, to identify distinct genetic groups for the retention of germplasm [29], second, to identify genes that correspond to important phenotypic traits and genetic shifts during domestication approach, third, is to find the aspects of history and timing of domestication.

The SSR primers used in the present study amplified an average number of 2.61 alleles per locus with a gene diversity value of 0.43 . Li et al. [30] reported 19.7 alleles per locus with gene diversity value of 0.72 during characterization of 1863 Chinese soybean landraces with 59 SSR markers. Similarly, Guan et al. [31] reported 16.2 alleles per locus with a gene diversity of 0.84 while comparing the genetic diversity of 205 Chinese landraces and also Liu et al. [32] reported 7.14 alleles per locus in his study on 91 Shaanxi soybean landraces. These reports show a higher number of alleles per locus in comparison to present study. Doldi et al. [33] reported two to six alleles per locus during characterization of 18 soybean cultivars using 12 microsatellite primers and Tantasawat et al. [34] reported 4.82 alleles per locus. Therefore, allelic richness (average number of alleles per locus) is an effective index for diversity evaluation but it is largely dependent on the sample size [35]. Hence to improve the allelic richness more landraces needs to be introduced into the system thus, enhancing genetic diversity. The mean PIC value obtained in the present study was 0.36 , where sat 180 , sat 600 , sat 554 and sat 478 are having 4 alleles per locus and PIC value

Table 4 Summary of AMOVA for three soybean populations

\begin{tabular}{llrlcl}
\hline Source & df & \multicolumn{1}{c}{ SS } & MS & Est. Var. & $\%$ \\
\hline Among Pops & 10 & 164.219 & 16.422 & 0.628 & $12 \%$ \\
Among Indiv & 66 & 528.158 & 8.002 & 3.443 & $66 \%$ \\
Within Indiv & 74 & 86.000 & 1.162 & 1.162 & $22 \%$ \\
Total & 150 & 778.377 & & 5.188 & $100 \%$ \\
\hline
\end{tabular}

between 0.55-0.66. These markers with high PIC values become informative for distinguishing among the soybean genotypes. Similar values have been reported by Zhang et al. [36] (0.38), Hisano et al. [37] (0.40), Wang et al. [35] (0.50) and Kim et al. [38] (0.87) with good genetic diversity in their set of samples. As a self -fertilizing crop soybean is expected to have low heterozygosity than hybrid crops [36], here we got low heterozygosity (0.11) much lower than the value reported by Zhang et al. [36] (0.46). Li et al. [30] reported heterozygosity of 0.014 in grain soybean whereas, 0.069 and 0.446 were reported in wild soybean by Liu et al.[39] and Wang et al. [40] respectively. Gene diversity observed in the present study was 0.43 ; this low level of gene diversity may be ascribed to the emphasis on direct introductions from introduced germplasm and single cross hybrids in the soybean breeding programs. Therefore, diverse germplasm needs to be introduced for more genetic variability [41] Narvel et. al. [14] analyzed 79 elite soybean cultivars with 74 SSR markers showing a low value of gene diversity. Gene diversity reported by $\mathrm{Li}$ et al. [42] Wang et al. [43] and Hudcovicova and Kraic [44] showed a substantially higher -value i.e. $0.77,0.80$ and 0.71 respectively on different sets of soybean genotypes. Hierarchical clustering divided the soybean landraces into three distinct clusters, and yellow seed coat colour soybean got grouped into one cluster. In this study, seed coat colour based grouping was more logical than grouping based on geographical location. The analysis based on geographical location showed mixing of genotypes from one location to another location and indicated frequent seed exchange across the geographical location. But when cluster analysis was done based on seed coat colour, the yellow seed coat colour genotypes were grouped together except one genotype(IC-469881). This shows that yellow seed coat colour genotypes are a recent introduction into this area, and breeders have not utilized yellow seed colour genotypes in the breeding programs. Tantasawat et al. [34] reported four major clusters in 25 soybean genotypes analysed by 11 SSR markers. Wang et al. [40] obtained two groups with five wild soybean population assessed by ten SSR markers and Wen et al. [45] also reported two clusters while studying the evolutionary relationship among ecotypes of Glycine max and G. soja in China. Ghosh et al. [46] reported two clusters and six sub clusters while studying 32 soybean cultivars with 10 SSR markers. Hirota et al. [47] studied black soybean landraces of Tanba region and got two distinct clusters, where as three clusters were obtained by Kondetti et al. [48] while studying 55 Indian Soybean varieties. Population structure divided the soybean genotypes into six different populations. Qiu et al. [49] reported three populations as wild, semi wild and cultivated soybean from Yangstee 


\section{Principal Coordinates (PCoA)}

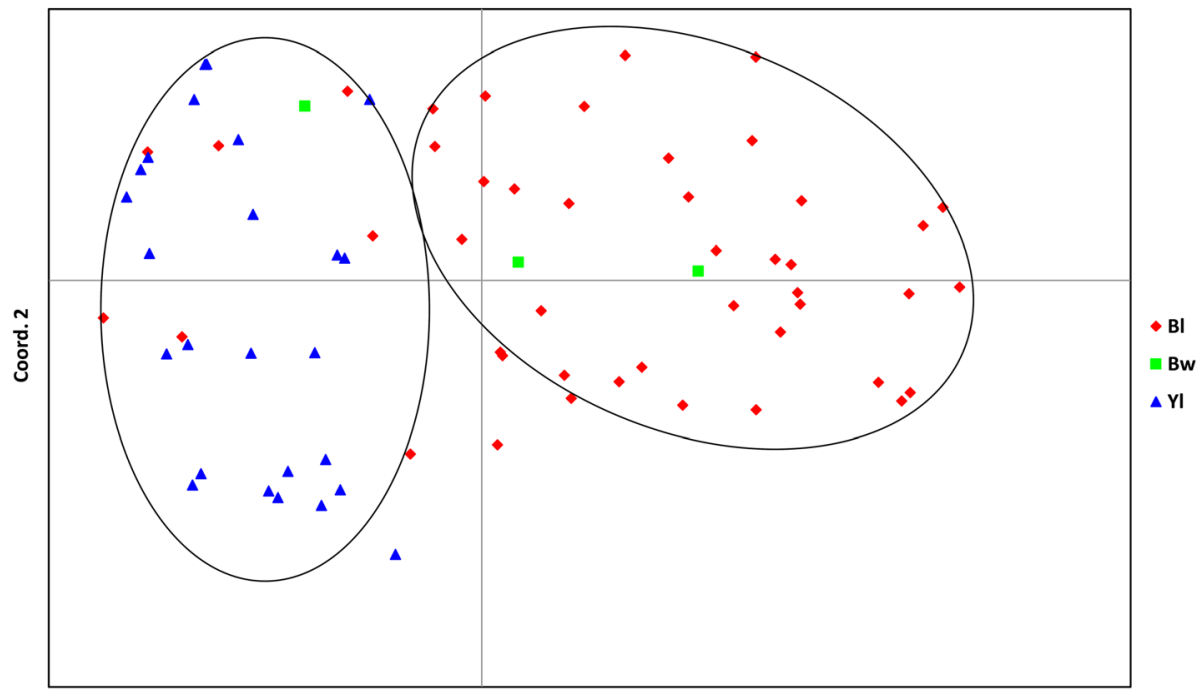

Coord. 1

Fig. 4 Principal Coordinate Analysis (PCoA) of 75 soybean genotypes (Populations based on seed coat colour)

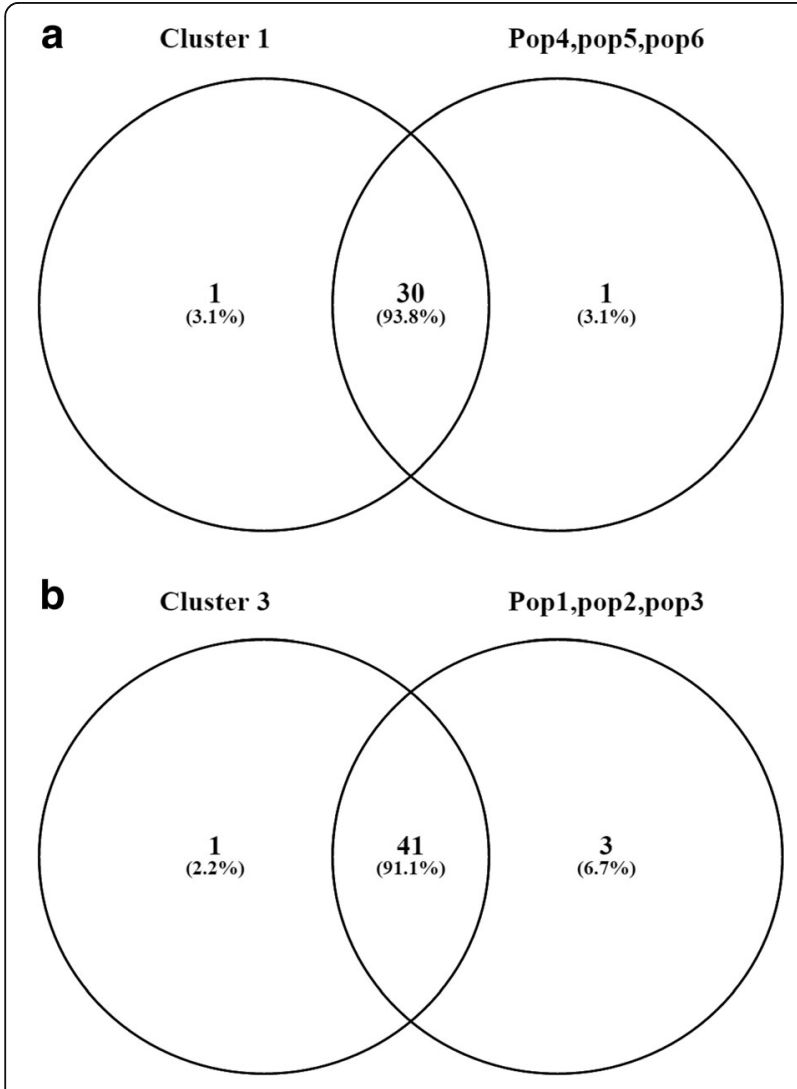

Fig. 5 a Venn diagram showing co linearity between cluster 1 and pop4, 5, 5 b Venn diagram showing co linearity between cluster 3 and pop1, 2, 3 region whereas; two populations were obtained by Chung et al. [50] in Korean wild and cultivated accessions of soybean and Gyu-Taek Cho et al. [51] reported three populations in Korean land races. PCoA analysis also showed consistent results when seen in terms of a grouping of landraces in cluster analysis. AMOVA showed $12 \%$ variance between populations, $22 \%$ variance within individuals and $66 \%$ variance among individuals. Since soybean is a self pollinated crop, therefore, less variation within individual and more variation among varieties/land races are expected. The analysis done by Venn diagrams showed that, more than $90 \%$ co-linearity between cluster 3 and pop1, pop2, pop3 and between cluster 1 and pop4, pop5, pop6. This study proves that SSR based genotyping is a better way to study the genetic diversity in soybean because grouping done by the Hierarchical method and population structure method were more than $90 \%$ similar.

\section{Conclusions}

Our study showed that Kala bhat, which has medicinal properties possess large diversity in comparison to yellow and brown seed coat soybean genotypes cultivated in Uttarakhand, India. This study confirms the hypothesis that the landraces are thought to possess rare alleles and therefore, good genetic diversity. This study also provides useful insights about the Kala bhat (black coloured soybean) among different districts of Uttarakhand and simultaneous isolation of yellow coloured soybean. Improving the genetic base requires an introduction of new alleles into the breeding program, and this can only be done by exploiting the genetic variability found in Kala bhat. 


\section{Abbreviations}

AMOVA: Analysis of molecular variance; PCoA: Principal Coordinate Analysis; PIC: Polymorphic information content; SSR: Simple sequence repeats

\section{Acknowledgements}

We are thankful to the Director, NBPGR, New Delhi, who provided facilities for this work. Financial support granted by Indian Council of Agricultural Research, New Delhi, India, is also gratefully acknowledged.

\section{Funding}

Indian Council of Agricultural Research, New Delhi, India.

\section{Availability of data and material}

All the details data and materials are given in this article.

\section{Authors' contributions}

Conceived and designed the experiments: RS, Performed the experiments: $\mathrm{YH}, \mathrm{DRC}$, Analyzed the data: DRC, RS, Contributed reagents/materials/analysis tools: VG, Wrote the paper: RS, YH and DRC. All authors read and approved the final manuscript.

\section{Competing interests}

The authors declare that they have no competing interests.

\section{Consent for publication}

Not applicable.

\section{Ethics approval and consent to participate}

Not applicable.

\section{Publisher's Note}

Springer Nature remains neutral with regard to jurisdictional claims in published maps and institutional affiliations.

\section{Author details}

'Division of Plant Genetic Resources, ICAR-Indian Agricultural Research Institute, New Delhi 110 012, India. '2Division of Genomic Resources, ICAR-National Bureau of Plant Genetic Resources, New Delhi 110 012, India. ${ }^{3}$ Division of Germplasm Conservation, ICAR-National Bureau of Plant Genetic Resources, New Delhi 110 012, India.

\section{Received: 8 December 2016 Accepted: 13 April 2017}

Published online: 27 April 2017

\section{References}

1. United States Department of Agriculture. USDA National Nutrient Database for Standard Reference Release 18. 2009. http://www.nal.usda.gov/fnic/ foodcomp/Data/SR18/sr18.html.

2. Singh RJ, Hymowitz T. Soybean genetic resources and crop improvement. Genome. 1999;42:605-16.

3. FAO FAOSTAT database. Food and Agriculture Organization of the United Nation, Rome, Italy. 2012. http://faostat.fao.org

4. Priestera JH, Gea Y, Mielkea RE, Horsta AM, Moritzb SC, Espinosae K, Gelbf J, Walkerg SL, Nisbetb RM, Ani Y, Schimelb JP, Palmere RG, HernandezViezcasc JA, Zhaoc L, Gardea-Torresdeyc JL, Holdena PA. Soybean susceptibility to manufactured nanomaterials with evidence for food quality and soil fertility interruption. Proc Natl Acad Sci U S A. 2012;109:2451-6. doi: 10.1073/pnas.1205431109.

5. Kayande NV, Patil SP. Genetic divergence in soybean [Glycine max (L.) Merril]. Int J Plant Sci. 2009;4:218-22.

6. Pawar KK, Yadav SK, Arman MJ, Singh AK. Assessment of divergence in soybean (Glycine max L. Merrill) germplasm for yield attributing traits. IJSR. 2013;2:1-2.

7. Sharma B, Singh BV, Singh K, Gupta AK, Gupta MK. Genetic divergence in Indian varieties of soybean [Glycine max (L.) Merrill]. Soybean Res. 2005:3:9-16.

8. Sihag R, Hooda JS, Vashistha RD, Malik BPS. Genetic divergence in soybean \{Glycine max (L.)Merill.\}. Ann Biol. 2004:20:17-21.

9. Bonato ALV, Calvo ES, Geraldi IO, Arias CAA. Genetic similarity among soybean (Glycine max (L.) Merrill) cultivars released in Brazil using AFLP markers. Genet Mol Biol. 2006;29:692-704.
10. Fu YB, Peterson GW, Morrison MJ. Genetic diversity of Canadian soybean cultivars and exotic germplasm revealed by simple sequence repeat markers. Crop Sci. 2007;47:1947-54.

11. Wang LX, Guan RX, Li YH, Lin FY, Luan WJ, Li W, Ma YS, Liu ZX, Chang RZ, Qiu L. Genetic diversity of chinese spring soybean germplasm revealed by SSR markers. Plant Breed. 2008;127:56-61.

12. Keim P, Beavis W, Schupp J, Freestone R. Evaluation of soybean RFLP marker diversity in adapted germplasm. Theor Appl Genet. 1992;85:205-12.

13. Maughan PJ, Saghai Maroof MA, Buss GR, Huestis GM. Amplified fragment length polymorphism (AFLP) in soybean: species diversity, inheritance and near isogenic line analysis. Theor Appl Genet. 1996;93:392-401.

14. Narvel JM, Fehr WR, Chu WC, Grant D, Shoemaker RC. Simple sequence repeat diversity among soybean plant introductions and elite genotypes. Crop Sci. 2000;40:1452-8

15. Powell W, Morgante M, Andre C, Hanafey M, Vogel J, Tingey S, Rafalski A. The comparison of RFLP, RAPD, AFLP and SSR (microsatellite) markers for germplasm analysis. Mol Breed. 1996:2:225-38.

16. Thompson J, Nelson RL. Utilization of diverse germplasm for soybean yield improvement. Crop Sci. 1998;38:1362-8.

17. Ude GN, Kenworthy WJ, Costa JM, Cregan PB, Alvernaz J. Genetic diversity of soybean cultivars from China, Japan, North America and North American ancestral lines determined by Amplified Fragment Length Polymorphism. Crop Sci. 2003:43:1858-67.

18. Shah NC. Black soybean: An ignored nutritious and medicinal food crop from the kumaon region of India. Asian Agri-History. 2006;10:33-42.

19. Oda MC, Sediyama T, Matsuo E, Cruz CD, de Barros EG, da S Ferreira MF. Phenotypic and molecular traits diversity in soybean launched in forty years of genetic breeding. Agron Sci Biotechnol. 2015;1:1-9.

20. Bharthiya A, Aditya JP, Pal RS, Kumar RA. Genetic variability in black soybean genotypes for agro-morphological and seed quality traits under rainfed condition of Uttarakhand hills. Soybean Res. (Special Issue). 2014;12(1):1-8.

21. Saghai-Maroof K, Soliman M, Jorgensen RA, Allard RW. Ribosomal DNA spacer-length polymorphisms in barley: Mendelian inheritance, chromosomal location, and population dynamics. Proc Natl Acad Sci. 1984; 81:8014-8.

22. Liu K, Muse SV. PowerMarker: integrated analysis environment for genetic marker data. Bioinformatics. 2005;21:2128-9.

23. Tamura K, Stecher G, Peterson D, Filipski A, Kumar S. MEGA6: Molecular Evolutionary Genetics Analysis version 6.0. Mol Biol Evol. 2013;30:2725-9.

24. Peakall $R$, Smouse. GenAlEx 6.5: genetic analysis in Excel Population genetic software for teaching and research-an update. Bioinformatics. 2012;28:2537-9.

25. Pritchard JK, Stephens M, Donnelly P. Inference of population structure using multilocus genotype data. Genetics. 2000;155:945-59.

26. Evanno G, Regnaut S, Goudet J. Detecting the number of clusters of individuals using the software STRUCTURE: a simulation study. Mol Ecol. 2005; 14:2611-20.

27. Oliveros JC, Venny. An interactive tool for comparing lists with Venn's diagrams. 2007. http://bioinfogp.cnb.csic.es/tools/venny/index.html.

28. Vinu V, Singh N, Vasudev S, Yadava DK, Kumar S, Naresh S, Bhat SR, Prabhu KV. Assessment of genetic diversity in Brassicajuncea (Brassicaceae) genotypes using phenotypic differences and SSR markers. Rev Biol Trop. 2013;61:1919-34.

29. Agrama HA, Yan WG, Lee F, Fjellstrom $R$, Chen $M H$, Jia M, McClung A. Genetic assessment of a mini-core subset developed from the USDA rice genebank. Crop Sci. 2009;49:1336-46.

30. Li Y, Guan R, Liu Z, Ma Y, Wang L, Li L, Lin F, Luan W, Chen P, Yan Z, Guan Y, Zhu L, Ning X, Smulders MJM, Li W, Piao R, Cui Y, Yu Z, Guan M, Chang R, Hou A, Shi A, Zhang B, Zhu S, Qiu L. Genetic structure and diversity of cultivated soybean (Glycine max (L.)Merr.) landraces in China. Theor Appl Genet. 2008;117:857-71.

31. Guan RG, Chang R, Li Y, Wang L, Liu Z, Qiu L. Genetic diversity comparison between Chinese and Japanese soybeans (Glycine max (L.) Merr.) revealed by nuclear SSRs. Genet Resour Crop Evol. 2010;57:229-42.

32. Liu M, Zhang M, Jiang W, Sun G, Zhao H, Hu S. Genetic Diversity of Shaanxi soybean Landraces based on agronomic traits and SSR markers. African J Biotechnol. 2011;10:4823-37.

33. Doldi ML, Vollmann J, Lelley T. Genetic diversity in soybean as determined by RAPD and microsatellite analysis. Plant Breed. 1997;116:331-5.

34. Tantasawat $P$, Trongchuen J, Prajongjai $T$, Jenweerawat S, Chaowiset W. SSR analysis of soybean (Glycine max (L.) Merr.) genetic relationship and variety identification in Thailand. Aust J Crop Sci. 2011;5:283-90. 
35. Wang LX, Guan RX, Liu ZX, Chang RZ, Qiu LJ. Genetic diversity of chinese cultivated soybean revealed by SSR markers. Crop Sci. 2006;46:1032-8.

36. Zhang $G, X u S, M a o$ W, Hu Q, Gong Y. Determination of the genetic diversity of vegetable soybean [Glycine max (L.) Merr.] using EST-SSR markers. J Zhejiang Univ Sci B (Biomed \& Biotechnol). 2013;14(4):279-88.

37. Hisano H, Sato S, Isobe S, Sasamoto S, Wada T, Matsuno A, Fujishiro T, Yamada M, Nakayama S, Nakamura Y, Watanabe S, Harada K, Tabata S. Characterization of the soybean genome using EST-derived microsatellite markers. DNA Res. 2007;14:271-81.

38. Kim KS, Chirumamilla A, Hill CB, Hartman GL, Diers BW. Identification and molecular mapping of two soybean aphid resistance genes in soybean PI 587732. Theor Appl Genet. 2014;127:1251-9.

39. Liu YL, Li YH, Zhou GA, Uzokwe N, Chang RZ, Chen SY, Qiu LJ.

Development of soybean EST-SSR markers and their use to assess genetic diversity in the Subgenus soja. Agric Sci China. 2010;9:1423-9.

40. Wang YH, Zhang XJ, Fan SJ. Genetic diversity of wild soybean populations in Dongying, China, by simple sequence repeat analysis. Genet Mol Res. 2015;14:11613-23.

41. Bisen A, Khare D, Nair P, Tripathi N. SSR analysis of 38 genotypes of soybean (Glycine Max (L.) Merr.) genetic diversity in India. Physiol Mol Biol Plants. 2015;21:109-15.

42. Li AQ, Zhao CZ, Wang XJ, Liu ZJ, Zhang LF, Song GQ, Yin J, Li CS, Xia H, Bi YP. Identification of SSR markers using soybean (Glycine max) ESTs from globular stage embryos. Electron J Biotechnol. 2010;13:1-11.

43. Wang KJ, Takahata Y. A preliminary comparative evaluationof genetic diversity between Chinese and Japanese wild soybean (Glycine soja) germplasm pools using SSR markers. Genet Resour Crop Evol. 2007;54:157-65.

44. Hudcovicova M, Kraic J. Utilisation of SSRs for characterization of the soybean (Glycine max (L.) Merr.) genetic resources. Czech J Genet Breed. 2003:39:120-6.

45. Wen ZX, Zhao TJ, Zheng YZ, Liu SH, Wang CE, Wang F, Gai JY. Association analysis of agronomic and quality traits with SSR markers in Glycine max and Glycine soja in China: I. Population structure and associated markers. Acta Agronomica Sinica. 2008;34:1169-78.

46. Ghosh J, Ghosh PD, Choudhury PR. An assessment of genetic relatedness between soybean [Glycine max (L.) Merrill] Cultivars using SSR markers. Am J Plant Sci. 2014:5:3089-96.

47. Hirota T, Sayama T, Yamasaki M, Sasama H, Sugimoto T, Ishimoto M, Yoshida S. Diversity and population structure of black soybean landraces originating from Tanba and neighboring regions. Breed Sci. 2012;61:593-601.

48. Kondetti P, Jawali N, Apte SK, Shitole MG. Comparative study of genetic diversity in Indian soybean (Glycine max L. Merr.) by AP-PCR and AFLP. Ann Biol Res. 2012;3:3825-37.

49. Qiu J, Wang Y, Wu S, Wang Y-Y, Ye C-Y, Bai X, Li Z, Yan C, Wang W, Wang Z, Shu Q, Xie J, Lee SH, Fan L. Genome re-sequencing of semi-wild soybean reveals a complex Soja population structure and deep introgression. PLoS One. 2014;9:e108479

50. Chung WH, Jeong N, Kim J, Lee WK, Lee YG, Lee SH, Yoon W, Kim JH, Choi IY, Choi HK, Moon JK, Kim N, Jeong SC. Population structure and domestication revealed by high-depth resequencing of Korean cultivated and wild soybean genomes. DNA Res. 2014;21:153-67.

51. Gyu-Taek C, Jeongran L, Jung-Kyung M, Mun-Sup Y, Hyung-Jin B, JungHoon K, Tae-San K, Nam-Chon P, Paek P. Genetic diversity and population structure of korean soybean landrace [Glycine max (L.) Merr.]. J Crop Sci Biotech. 2008;11:83-90.

\section{Submit your next manuscript to BioMed Central and we will help you at every step:}

- We accept pre-submission inquiries

- Our selector tool helps you to find the most relevant journal

- We provide round the clock customer support

- Convenient online submission

- Thorough peer review

- Inclusion in PubMed and all major indexing services

- Maximum visibility for your research

Submit your manuscript at www.biomedcentral.com/submit

Biomed Central 